\title{
MATERIAL CULTURE OF POST-COLONIAL WILDLIFE TOURISM
}

\author{
Ralf Buckley \\ Griffith University, Australia
}

Many independent nations with strong tourism economies have colonial pasts. In parts of Africa and Asia, former colonial powers have left post-colonial legacies of language, buildings, trade and diplomatic links, and government bureaucratic structures (Ashcroft, Griffiths, \& Tiffin, 2007; Sharp, 2009; Zein-Alabdin, 2009). There are also strong postcolonial influences on tourism (Carrigan, 2011; Hall \& Tucker, 2004; Tucker \& Abama, 2009). These range from large-scale factors such as key markets and land-use allocation (Akama, Maingi, \& Camargo, 2011; Nelson, 2010), to localised concerns such as the authenticity of performances (Martin, 2010). In nations such as India, the newly wealthy middle class may use tourism to sample former colonial lifestyles (Bandyopadhyay, 2012).

This analysis examines one particular localised influence, namely the material culture (Haldrup \& Larsen, 2006; Olsen, 2010) of individual tourism products. It focusses on architecture and interior design of small-scale, upmarket wildlife lodges in countries once associated with the British Empire, in the subcontinents of India and sub-Saharan Africa. The perspective presented here is thus itself necessarily a form of postcolonial analysis, an academic comprador approach (Ashcroft et al., 2007).

Data are derived from on-site audits between 2000 and 2011 (Buckley 2006, 2010), of 37 such establishments selected because of their international awards, certificates and reputation for quality of product and service (Eco-Luxury, 2012; Relais et Chateaux, 2012; Small Luxury Hotels of the World, 2012). Interior and exterior design features and fittings were documented photographically. They are also illustrated on the individual lodge websites and those of the syndicates listed above. The focus is on the areas used by tourists, rather than those restricted to staff.

Many of the tourists visiting these lodges originate from the UK and other European nations with colonial histories, or from North and South American nations which share the colonial portions of those histories. This provides these operators with opportunities to use colonial 
connotations in material culture, both as a tool in tourism marketing, and in the choreography of tourist experiences. This entire tourism sector may be seen from a postcolonial perspective (Akama et al., 2011), but the current analysis is restricted to material culture. In particular, this analysis does not examine any possible postcolonial elements in the relations between owners and staff, or guests and guides.

In the Sabi Sands Private Reserve area adjacent to Kruger National Park in South Africa, lodges such as Chitwa Chitwa, Selati, and Kirkmans reflect architecture and furniture from the era of hunting safaris, including colonial-era hunting rifles. In Namibia, Desert Rhino Tented Camp uses a classic colonial-era hunting-camp layout. In the Serengeti region of northern Tanzania, Grumeti Camp is constructed as a colonial-era double-walled canvas tented camp. In northern Botswana, Zarafa Camp uses colonial-era design elements such as enamel baths sheathed with beaten copper, wooden writing desks with retro-styled lamps, stuffed leather armchairs of dark maroon, and heavy-duty brass-cornered wooden travelling trunks (Figure 1). These items, though beautifully made, are of recent manufacture. Similar approaches are used at Selinda and Duba Plains. Xudum Lodge follows a theme from colonial-era hunting lodges, with overstuffed leather couches in dark browns, reds and blues. At Jacks Camp in southwestern Botswana, water is hand-delivered to copper washbasins on tripods at each guest tent, copying colonial-era safari practices.

Lodges in the tiger reserves of Madhya Pradesh in central India also use a range of colonialera elements. At Mahua Kothi, the central lounge and dining area is a colonial-era building. At Pashan Garh, there is a beautifully carved central dining table of inlaid marble, a recent copy of an older style. At Bhagvan, the guest quarters include outdoor bedrooms built in the style of a machan. These are raised platforms, designed historically for surveillance and safety by villagers protecting crops and livestock against marauding animals, and later adapted for colonial-era hunting parties.

Colonial-era design elements, however, are by no means ubiquitous. Kleins Camp in Tanzania uses stone rondavels which reflect local rather than colonial architectural tradition. Earth Lodge in South Africa's Sabi Sands area uses earth-roofed concrete structures. Xaranna lodge in Botswana is decorated in pastel pink, green and beige, with white carved hippopotami throughout. Kalahari Plains in Botswana, and Damaraland and Serra Cafema in Namibia, use modern design motifs, with elements reflecting local nature and culture. For 
example, this includes sculptures echoing the shape of spears or plant fruits. North Island in the Seychelles, and Mnembe in Zanzibar, re-use local materials such as tree-trunks, for construction as well as design. At Ongava, Vumbura, Mombo and Savuti in Botswana, there are blends of colonial-era and modern design elements.

The principal findings may thus be summarised as follows. Firstly, a number of the more upmarket lodges in the former British Empire have indeed adopted colonial-era motifs in both their exterior and interior design. Secondly, these are by no means universal: many other design motifs are also used. Thirdly, whilst some items of material culture are re-used colonial-era objects such as buildings, furniture and firearms, most are well-made but recent copies.

The re-used items are genuine original artefacts, authentic in the material sense (Jones, 2010); but they are now used for décor rather than function. Hunting rifles, for example, are hung on walls, not kept in gun cases. The designers' aim is aura rather than authenticity (Rickly-Boyd, 2012). Newly made copies of colonial-era items, reflecting how the original items appeared to their owners, may well provide a more authentic tourist experience than a genuine original subject to heavy wear and tear. The tourists are attracted principally by wildlife, and the material items are there to create comfort and ambience. Authenticity is thus less significant than for, e.g., tourist products focussed on art or archaeology, history or culture.

Taken together, these findings suggest that tour operators do indeed perceive commercial value in colonial-era nostalgia, for at least some of their clients, some of the time. Colonialera décor can also provide comfort, but this could equally be provided by different designs and modern fixtures, so comfort alone does not provide adequate explanation. The recently manufactured copies of colonial-era items are much more expensive than modern functional equivalents. Colonial nostalgia is also reflected in marketing materials, which exhort tourists to experience "nostalgic safaris, reminiscent of the great African explorers" (Austin-Lehman Adventures, 2012).

Colonial-era themes are also reflected in the souvenirs, clothing and jewellery sold by these upmarket lodges, and bought or worn by the tourists. These too are part of the material culture of tourism (Hitchcock \& Teague, 2000). The tourists may wear silks sold by expensive fashion houses, but the designs, colours and patterns they choose for their African 
and Indian holidays mimic colonial-era safari garb. Similar analyses for these other material elements, for human relations, and for other geographic regions and past colonial powers might thus provide a valuable comparison with the result reported above. 


\section{REFERENCES}

Akama, J. S., Maingi, S., \& Camargo, B. A. (2011). Wildlife conservation, safari tourism and the role of certification in Kenya: A postcolonial critique. Tourism Recreation Research, 36, 281-291.

Ashcroft, B., Griffiths, G., \& Tiffin, H. (2007). Post-colonial studies: The key concepts (2nd ed.). Oxford: Routledge.

Austin-Lehman Adventures (2012). Botswana Safari Tours. http://www.austinlehman.com/tours/great-wilderness-journey-botswana-tour-trips-124.php Retrieved 16.06.12.

Bandyopadhyay, R. (2012). "To be an Englishman for a day": Marketing colonial nostalgia in India. Annals of Tourism Research, 3, 1245-1248.

Buckley, R. C. (2006). Adventure tourism. Oxford: CABI.

Buckley, R. C. (2010). Conservation tourism. Oxford: CABI.

Carrigan, A. (2011). Postcolonial tourism: Literature, culture, and environment. Oxford:Routledge.

Eco-Luxury (2012). Retreats of the World. <http://www.ecoluxury.com> Retrieved 01.09.2012.

Haldrup, M., \& Larsen, J. (2006). Material cultures of tourism. Leisure Studies, 25, 275-289.

Hall, C. M., \& Tucker, H. (2004). Tourism and postcolonialism: Contested discourses, identities and representations. Oxford: Routledge.

Hitchcock, M., \& Teague, K. (2000). Souvenirs: The material culture of tourism. Wallingford: CABI.

Jones, S. (2010). Negotiating authentic objects and authentic selves: Beyond the deconstruction of authenticity. Journal of Material Culture, 15, 181-203. 
Martin, K. (2010). Living pasts: Contested tourism authenticities. Annals of Tourism Research, 37, 537-554.

Nelson, F. (2010). Community rights, conservation and contested land: The politics of natural resource governance in Africa. London: Earthscan.

Olsen, B. (2010). In defence of things. Plymouth: Altamira.

Relais et Chateaux (2012). Partout dans le monde, unique au monde. <http://www.relaischateaux.com> Retrieved 01.09.12.

Rickly-Boyd, J. M. (2012). Authenticity \& aura: A Benjaminian approach to tourism. Annals of Tourism Research, 39, 269-289.

Sharp, J. (2009). Geographies of postcolonialism. London: Sage.

Small Luxury Hotels of the World (2012). Experience another world. <http://www.slh.com> Retrieved 01.09.2012.

Tucker, H., \& Abama, J. (2009). Tourism as postcolonialism. In T. Jamal \& M. Robinson (Eds.), The SAGE handbook of tourism studies (pp. 504-520). London:Sage.

Zein-Alabdin, E. O. (2009). Economics, postcolonial theory and the problem of culture: Institutional analysis and hybridity. Cambridge Journal of Economics, 33, 1153-1167. 